\title{
Hukum Pernikahan Janda Dalam Masa 'Iddah Menurut Pandangan Ulama Palangka Raya
}

\author{
Jauharataun \\ IAIN Palangka Raya \\ Jauhratun19@gmail.com
}

\begin{abstract}
The begraund of this research is widow marriage law in the iddah period according to Palangka Raya religious adviser on religious law. The fact is the woman completed the trial court divorce then remarry without spending that iddah period consistently. The objective of this research are: How is the law status widow marriage in the iddah period according to religious adviser on religious law? What is law used to answer the problem of widow marriage in the 'iddah period according to religious adviser on religious law?. This study is sociological law research or empirical which use descriptive qualitative approach. The data is collected by interviewing and documentation and validated with source triangulation technique. The data analyzed in three steps are reduction, display and conclusion drawing/classification. The result of this research conclude that: According Palangka Raya religious adviser on religious law widow marriage in the iddah period is haram because it is imperfect which caused damaged to one of the conditions of marriage. The most important widow marriage legals in the waiting period are Al-Qur'an, Surah At-Thalaq paragraphs 1, 2, 4, 6, dan 7 and Surah Al-Baqarah paragraphs 228-234. There is provision of marriage law in Indonesia number 1 of 1974.
\end{abstract}

Keywords: Widow marriage law, the waiting period, Palangka Raya religious adviser on religious law. 


\section{A. Pendahuluan}

Pernikahan merupakan ikatan batin seorang pria dan wanita sebagai suami istri dengan membentuk keluarga yang bahagia dan kekal berdasarkan Tuhan Yang Maha Esa. Dalam Islam pernikahan masuk dalam kategori ibadah. ${ }^{1}$ Pernikahan juga merupakan salah satu sunnatullah atas seluruh ciptaan-Nya, tidak terkecuali manusia, hewan dan tumbuh-tumbuhan. ${ }^{2}$ Sesuai dengan firman Allah Swt. dalam surat Ar-Rum [30]: 21 telah diterangkan dalam Islam, tujuan perkawinan ialah mentaati perintah Allah Swt. untuk memperoleh keturunan yang sah dalam masyarakat, dengan mendirikan rumah tangga yang damai dan teratur. ${ }^{3}$ Namun, ketika terjadi perpecahan rumah tangga, maka hal ini menandakan bahwa tujuan pernikahan tidak tercapai dan berujung pada perpisahan dengan jalan perceraian. Dalam Fiqih Imam Syafi'i, Abu Dawud meriwayatkan bahwa Nabi Muhammad Saw. bersabda, "Tidak ada perbuatan halal yang lebih dimurkai Allah selain talak." (HR. Abu Dawud dengan sanad yang shahih dan al-Hakim yang menshahihkan hadis ini). Kemudian para ulama telah sepakat bahwa talak itu disyariatkan. ${ }^{4}$

M. Ansyari MK, berkaitan dengan aturan administratif perceraian dalam bukunya yang berjudul Hukum Perkawinan di Indonesia menjelaskan bahwa:

Dalam Pasal 65 Undang-Undang Nomor 7 Tahun 1989 yang telah diubah dengan Undang-Undang Nomor 3 Tahun 2006 Jo Pasal 39 Undang-Undang Nomor 1 Tahun 1974 ditegaskan bahwa: "Perceraian hanya dapat dilakukan di depan sidang Pengadilan setelah Pengadilan yang bersangkutan berusaha dan tidak berhasil mendamaikan kedua belah pihak." Selanjutnya di dalam angka 7 Penjelasan Umum Undang-Undang Nomor 7 Tahun 1989 ditegaskan bahwa: "Undang-

${ }^{1}$ Zainuddin Ali, Hukum Perdata Islam di Indonesia, Jakarta: Sinar Grafika, 2009, h. 7.

${ }^{2}$ Abdul Azziz Muhammad Azzam dan Abdul Wahab Sayyed Hawwas, Fiqh Munakahat: Khitbah, Nikah, dan Talak, Alih bahasa Abdul Majid Khon, Jakarta: Amzah, 2009, h. 37.

${ }^{3}$ Yunus Mahmud, Hukum Perkawinan dalam Islam, Jakarta: CV Al Hidayah, 1964, h. 1.

${ }^{4}$ Wahbah Zuhaili, Fiqih Imam Syafi'i: Mengupas Masalah Fiqhiyah Berdasarkan AlQur'an dan Hadits 2, Jakarta: Almahira, 2010, h. 580. 
Undang Perkawinan bertujuan antara lain melindungi kaum wanita pada umumnya dan pihak istri pada khususnya ..."5

Selanjutnya ada kewajiban masa 'iddah bagi wanita yang mengalami perceraian. Telah ditegaskan dalam Al-Qur'an bahwa dalam keadaan apapun yang dialami pihak wanita, ia wajib melaksanakan iddah. Allah Swt. berfirman,

Terjemahan: "Dan para istri yang diceraikan (wajib) menahan diri mereka (menunggu) tiga kali quru' ..." Q.S. Al-Baqarah [2]: $228 .^{6}$

Telah dijelaskan dalam Al-Qur'an, bahwa ada beberapa adab ber'iddah, yakni tidak keluar rumah dan tidak berhias, baik dikarenakan cerai hidup atau cerai mati. Tentu perintah dalam Al-Qur'an memiliki hikmah di setiap aturannya. Adapun penyesuaian hukum dari adab perempuan janda dalam konteks kekinian dapat di kaji menggunakan teori kaidah ushul fikih yang berbunyi, تغير الاحكام بتغير الازمنة و الامكنة و الاحوال, “Perubahan hukum itu berdasarkan perubahan zaman, tempat dan keadaan." Artinya, perubahan hukum sesuai dengan perubahan situasi dan kondisi suatu zaman, namun tetap berada dalam ketentuan yang disyariatkan. Misalnya janda dengan profesi sebagai PNS (Pegawai Negeri Sipil) di zaman sekarang, maka diberi keringanan hukum atas dirinya untuk berhias dengan wajar dan tidak berlebih-lebihan. Tetap menjaga tujuan utama dijalankannya masa iddah sebagai masa transisi dengan menyempurnakan adab. Agar tidak menimbulkan indikasi untuk melakukan pernikahan dalam masa iddah. $^{7}$ Jumhur ulama kecuali Imam Hasan al Basri sepakat mengatakan bahwa salah satu perkara yang wajib dilaksanakan perempuan dalam masa iddah adalah ihdad. Yaitu meninggalkan perbuatan seperti berhias diri agar tidak menarik perhatian laki-laki lain.

${ }^{5}$ M. Ansyari MK, Hukum Perkawinan di Indonesia, Yogyakarta: Pustaka Pelajar, 2010, h. 76. Lihat: Tim Penyusun, Undang-Undang Republik Indonesia No. 1 Tahun 1974 tentang Perkawinan \& Kompilasi Hukum Islam, Bandung: Citra Umbara, 2011.

${ }^{6}$ Dewan Penterjemah, Al Qur'an, 1971, h. 55.

${ }^{7}$ Rasyid Rijani, Kaidah Fiqh tentang Pencatatan Perkawinan dan Perceraian, http://konsultasi-hukum-online.com/2013/05/kaidah-kaidah-fiqhiyyah-tentang-pencatatanperkawinan-di-kua-dan-perceraian-di-pengadilan-agama/, di akses pada 20 November 2015. 
Dalam Al-Qur'an, tidak dibenarkan bagi perempuan-perempuan yang sedang menjalani masa 'iddah untuk bersuami lagi. ${ }^{8}$ Ketentuan mengenai keharaman nikah dalam masa 'iddah ini juga disebutkan dalam Kompilasi Hukum Islam (selanjutnya di sebut KHI) Indonesia BAB VI Pasal 40 huruf b tentang Larangan Kawin, bahwa dilarang melangsungkan pernikahan apabila seorang wanita masih berada dalam masa 'iddah dengan pria lain. ${ }^{9}$

Adapun salah satu bentuk kepedulian umat Islam mengenai tujuan hukum Islam yang harus dicapai dalam hal nikah, talak, dan iddah, diwujudkan dengan adanya perhatian khusus dari Ulama besar Islam khususnya di Palangka Raya. Sebagaimana yang dikatakan oleh Ustadz Yamin Mukhtar pada pertemuan pertama, bahwa kasus hukum seperti ini merupakan perihal yang harus diperhatikan secara khusus karena berkaitan langsung dengan dampak-dampak hukum yang akan terjadi setelahnya. Selanjutnya, berpedoman dengan kaidah fikih siyasah dijelaskan bahwa,

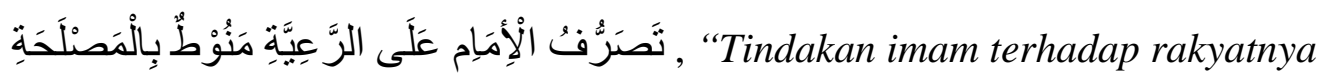
harus dikaitkan dengan kemaslahatan." (sebagai imam umat Islam) dalam menfatwakan sesuatu yang bertujuan untuk kemashlahatan, dapat diambil sebagai panutan. Menanggapi perihal di atas, maka penulis tertarik mengangkat judul: Hukum Pernikahan Janda Dalam

\section{Masa 'Iddah Menurut Pandangan Ulama Palangka Raya.}

\section{B. Kajian Pustaka}

Pembahasan mengenai 'iddah cukup memiliki magnet perhatian dari kalangan studi hukum Islam terkhusus pada mahasiswa yang menggeluti Fakultas Syariah di Indonesia. Penulis menelusuri penelitian terdahulu yang membahas pada konsentrasi 'iddah janda, namun penulis hanya menemukan

\footnotetext{
${ }^{8}$ Sayyid Sabiq, Fiqih Sunnah 3, Alih bahasa M. Ali Nursyidi dan Hunainah M. Thahir Makmun, Jakarta: PT. Pena Pundi Aksara, 2009, h. 117.

${ }^{9}$ Tim Penyusun, Himpunan Peraturan Perundang-Undangan Tentang Kompilasi Hukum Islam, Bandung: Fokus Media, 2007, h. 16.

${ }^{10}$ Nurvita Diah Rahayu, Kaidah Fiqhiyah, http://nurvita-diahrahayu.blogspot.co.id/2012/03/kaidah-fiqhiyah.html, di akses tanggal 20 November 2015 .
} 
dua penelitian yang sama persis dan satu penelitian lain yang tidak sama persis, namun masih dalam lingkup 'iddah.

Hasil penelusuran penulis yang pertama adalah sebuah skripsi seorang mahasiswi Institut Agama Islam Negeri (IAIN) Tulungagung bernama Fyna Khairunnisa Rahmawati dengan judul Tinjauan Hukum Islam terhadap Dispensasi Menikah dalam Masa Iddah (Studi Kasus Putusan Nomor 005/Pdt.P/2013/PA.TA di Pengadilan Agama Tulungagung, yang di dalam penelitiannya juga membahas permohonan seorang janda untuk melakukan perkawinan, namun ditolak pihak KUA karena masih dalam masa iddah. Kemudian wanita janda tersebut mengajukan permohonan dispensasi perizinan perkawinan dalam masa 'iddah dikarenakan dirinya hamil (dengan kekasihnya) pada Pengadilan Agama setempat, namun tetap ditolak karena harus menyelesaikan 'iddah terlebih dahulu. ${ }^{11}$

Hasil penelusuran yang kedua adalah skripsi dari salah satu mahasiswa Sekolah Tinggi Agama Islam Palangka Raya pada tahun 2007 dengan judul "Pengabaian Masa Idah (Studi Kasus di Kecamatan Kurun Kabupaten Gunung Mas)”. Peneliti memaparkan bahwa faktor terjadinya pernikahan bawah tangan yang masih berada dalam masa iddah adalah karena perselingkuhan, dan kedua pasangan tinggal satu rumah sebelum nikah. Peneliti juga menjelaskan bagaimana dampak dari pernikahan terlarang ini, bahwa pasangan tidak akan mendapatkan akta nikah, kurang harmonisnya hubungan keluarga, keterlantaran anak terutama dalam hal pendidikan serta hal-hal lain. ${ }^{12}$

Terakhir adalah dari Munasir, mahasiswa Sekolah Tinggi Agama Islam Negeri Palangka Raya pada tahun 2014 dengan judul "Penetapan Masa Idah Wanita yang Dicerai dalam Perspektif Empat Imam Mazhab Fikih dan Hakim Pengadilan Agama Kota Palangkaraya”. Secara garis besar skripsi ini

\footnotetext{
${ }^{11}$ Skripsi Fyna Khairunnisa Rahmawati. Lihat: http://repo.iaintulungagung.ac.id/768/5/BAB\%20IV.pdf, di akses tanggal 16 April 2015.

${ }^{12}$ Benri, "Pengabaian Masa Idah (Studi Kasus di Kecamatan Kurun Kabupaten Gunung Mas", Skripsi Sarjana, Palangkaraya: Sekolah Tinggi Agama Islam Negeri (STAIN) Palangkaraya, 2007, t.d.
} 
meneliti dengan pendekatan kualitatif normatif yuridis, dengan berlandaskan Al-Qur'an Surat Al Baqarah ayat ke 228 dan PP. No. 9 Tahun 1975 Pasal 39 Ayat 3 Tentang Pelaksanaan UU No. 1 Tahun $1974 .{ }^{13}$

\section{Metode Penelitian}

Adapun dalam penelitian ini, peneliti memakai penelitian hukum sosiologis atau empiris yang ranahnya berkisar pada tatanan masyarakat. Peneliti melakukan penelitian terhadap data primer yang merupakan data empiris yang diperoleh langsung dari sumber data, yakni pandangan beberapa Ulama Palangka Raya tentang pernikahan janda dalam masa iddah di Kota Palangka Raya.

Penelitian ini merupakan penelitian lapangan atau field research dengan menggunakan pendekatan kualitatif deskriptif, yakni penelitian dengan menggunakan bahan-bahan lapangan seperti hasil wawancara, hasil observasi yang mendalam dengan menggunakan pedoman interview wawancara yang sesuai dengan kondisi lapangan.

\section{Pembahasan}

Mencermati kembali hasil kuesioner dan wawancara dengan beberapa Ulama yang menjadi subjek penelitian ini, dari ke 5 (lima) subjek yang bernama Ustadz Yamin Mukhtar, Ustadz Chairuddin Halim, Ustadz Adri Nasution, Ustadz Iskandar Arsyad dan Ustadz Surya Langka tersebut, secara umum memiliki kesamaan pendapat bahwa pernikahan janda dalam masa 'iddah adalah bersifat batal dan hukumnya haram.

Subjek penelitian yang bernama Ustadz Yamin Mukhtar (Ketua FKUB Provinsi Kalimantan Tengah), secara umum memberikan pendapat tentang hukum pernikahan janda dalam masa 'iddah adalah tidak sah. Beliau mengatakan masalah perkawinan, talak dan 'iddah sudah rinci dijelaskan dalam Al-Qur'an. 'Iddah menjadi hal yang sangat penting, sehingga jika terjadi pernikahan sedangkan 'iddah yang dijalani belum habis, maka pernikahannya tidak sah.Kondisi perempuan yang masih menjalani masa

${ }^{13}$ Munasir, "Penetapan Masa Idah Wanita yang Dicerai dalam Perspektif Empat Imam Mazhab Fikih dan Hakim Pengadilan Agama Palangkaraya”, Skripsi Sarjana, Palangkaraya: Sekolah Tinggi Agama Islam Negeri (STAIN) Palangkaraya, 2014, t.d. 
'iddah itu akan menjadi penghalang baginya untuk menikah lagi.Karena perempuan yang tengah menjalankan masa iddah talak raj'i merupakan perempuan yang tidak boleh dipinang.

Ali Yusuf As-Subki dalam bukunya Fiqh Keluarga memaparkan bahwa salah satu penyebab perempuan-perempuan diharamkan sementara untuk menikah adalah wanita yang masih berada dalam masa 'iddah dari lakilaki lain. Pernikahan seorang wanita yang masih dalam masa 'iddah merupakan salah satu bentuk nikah yang rusak dan batal.Hal seperti ini mengakibatkan keduanya diharuskan untuk dipisah. Namun ketetapan mahar tetap bagi wanita meski ia tidak bercampur dengannya. Dan juga diharamkan bagi laki-laki tadi untuk menikahinya kembali, sebelum masa iddah-nya habis. Hal ini berdasarkan dari Firman Allah Swt Q.S. Al Baqarah [2]: 235.

Menanggapi masalah itu, Ustadz Chairuddin Halim menyatakan bahwa pernikahan janda dalam masa iddah dapat dilihat pada surat Al Baqarah ayat ke 228 dan 235, bahwa tidak ada toleransi terhadap kewajiban 'iddah dan perhitungannya. Karena 'iddah adalah salah satu ibadah wajib bagi perempuan yang menyandang status janda dalam pernikahan. Artinya, ketentuan-ketentuan Allah Swt. mengenai fikih itu tidak boleh dilanggar. Apabila pernikahan fasid seperti ini terjadi, maka akibathukum baru akan datang setelah hukum yang sebelumnya dilanggar, seperti status anak, waris, dan sebagainya.

Selanjutnya, sisa tanggungan masa iddah harus dilanjutkan perempuan itu sampai selesai, kemudian baru bisa menikah kembali.Hal ini sesuai dengan pendapat Imam Hanafi, Imam Syafi'i, dan Al Tsawriy bahwa, setelah pernikahan batal dan masa 'iddah habis, maka boleh kembali lagi. Karena pernikahan adalah hak suami istri selama tidak ada dalil yang melarangnya. ${ }^{14}$ Memiliki kesamaan argumentasi dengan Ustadz Yamin Mukhtar dan Ustadz Chairuddin Halim, Ustadz Adri Nasution selaku Penghulu KUA Kecamatan Pahandut Kota Palangka Raya, menegaskan

\footnotetext{
${ }^{14}$ Amir Syarifuddin, Hukum Pernikahan Islam di Indonesia: ANtara Fiqh Munakahat dan Undang-Undang Perkawinan, Jakarta: Kencana, 2009, h. 123.
} 
bahwa pernikahan yang terjadi dalam masa 'iddah adalah pernikahan yang batal. Karena jelas bertentangan dengan Al-Qur'an, hadis, ijma', dan qiyas, sebagai sumber Hukum Islam yang dipakai umat muslim. Jika terjadi, maka pernikahannya dianggap tidak sah menurut Agama dan juga ketentuan Undang-Undang yang berlaku di Indonesia. Dalam Undang-Undang No. 1 Tahun 1974 tentang Perkawinan Pasal 40 huruf b, telah jelas dikatakan bahwa seorang perempuan yang masih berada dalam masa iddah dengan laki-laki lain dilarang untuk melangsungkan pernikahan. Perbuatan hukum seperti ini jelas haram menurut Hukum Perkawinan Indonesia yang berpedoman pada Hukum Islam sendiri.

Begitu pula dengan pandangan Ustadz Iskandar Arsyad selaku unsur Ketua MUI Kota Palangka Raya Bidang Dakwah dan Pendidikan, bahwa kondisi pernikahan dalam masa 'iddah hukumnya adalah tidak boleh karena jelas dalam syariat. Adapun hikmah dari iddah bukan hanya untuk istibra rahim, disamping itu ada masa penyesuaian diri yakni untuk introspeksi diri.Sehingga setelah masa jatuhnya talak terjadi, tetap memberikan manfaat yang berguna selama menjalankan iddah. Menanggapi hal ini, maka benar 'iddah tidak bisa di rukhsah. Karena perihal 'iddah adalah pokok dan menyebabkan kewajiban.Sehingga jika hikmah 'iddah hanya untuk mengetahui kosongnya rahim saja, maka tujuan Hukum Islam mengenai perihal pernikahan tidak terpenuhi dengan sempurna. Jika iddah yang dijalani perempuan benar-benar hanya untuk mengetahui kosongnya rahim, kemudian perempuan itu tidak menjaga adabnya selama menjalankan iddah, maka ada indikasi yang mungkin terjadi bagi laki-laki untuk meminangnya (khitbah). Iddah yang dilakukan tanpa memperhatikan keharusan dan larangan, contohnya adab, maka 'iddah tidak akan sempurna. Selanjutnya akan berdampak pada dorongan fisik dan psikologis perempuan itu untuk menikah dengan laki-laki lain.

Adapun khitbah (pinangan) yang diatur dalam Hukum Islam adalah terhadap wanita ber- 'iddah talak raj'i, talak ba'in, talak khulu atau fasakh, 
dan 'iddah talak karena suami wafat. ${ }^{15}$ Adapun penjelasannya sebagai berikut: Perempuan dalam 'iddah talak raj’i, diharamkan untuk dipinang, baik secara sindiran maupun terang-terangan. Karena, 'iddah pada talak raj' $i$ tidak memutuskan hubungan suami istri seketika itu, dan suami masih memiliki hak untuk rujuk kepada istrinya. ${ }^{16}$ Perempuan dalam iddah talak ba'in qubra atau perempuan yang dicerai dan jatuh talak tiga kali, tidak diperbolehkan untuk dipinang kecuali dengan kalimat sindiran. ${ }^{17}$ Hal ini berdasarkan firman Allah Swt Q.S. Al Baqarah [2]: $235^{18}$ Perempuan dalam 'iddah talak ba'in shugra (talak karena khulu) atau perempuan yang tercerai dua kali, diharamkan untuk dipinang secara sindiran dan terang-terangan. Peminangannya akan menimbulkan kerusakan dalam pengakuan yaitu kebohongan selesainya masa 'iddah, sekalipun laki-laki meminang dengan sindiran. Karena perempuan yang berada dalam 'iddah talak ba'in shugra memiliki kemungkinan bagi suaminya untuk kembali dengan akad dan mahar baru. ${ }^{19}$ Perempuan dalam iddah karena wafatnya suami tidak diperbolehkan dipinang laki-laki lain dengan terang-terangan kecuali dengan sindiran. Sesuai surah Al Baqarah ayat ke 235. Karena ditakutkan jika terjadi pinangan secara jelas oleh pihak laki-laki lain, maka akan mendatangkan bencana. Seperti permusuhan antara peminang dan keluarga suami yang meninggal, kebencian keluarga suami yang meninggal terhadap yang dipinang, dan juga berkaitan dengan keharusan adab seorang janda ber- 'iddah karena kematian suaminya harus dilaksanakan, seperti meninggalkan hiasan yang mencolok dan tidak keluar rumah. ${ }^{20}$

\section{h. 19.}

${ }^{15}$ Abdul Aziz Muhammad Azzam dan Abdul Wahab Sayyed Hawwas, Fiqih Munakahat,

${ }^{16}$ Ibid.

${ }^{17}$ Ibid.

${ }^{18}$ Dewan Penterjemah, Al Qur'an, 1971, h. 59.

${ }^{19}$ Abdul Aziz Muhammad Azzam dan Abdul Wahab Sayyed Hawwas, Fiqih Munakahat, h. 23. Lihat juga: Departemen Agama RI, Al-Qur'an Bayan: Al-Qur'an dan Terjemahannya disertai Tanda-Tanda Tajwid dengan Tafsir Singkat, t.tm: Bayan Qur'an, 2009, h. 36. h. 25 .

${ }^{20}$ Abdul Aziz Muhammad Azzam dan Abdul Wahab Sayyed Hawwas, Fiqih Munakahat, 
Dalam ushul fikih, terdapat dalil-dalil hukum yang salah satunya adalah qiyas. Qiyas terbagi menjadi 4 macam, dan salah satunya adalah qiyas aulawi. Jika dalam menentukan hukum pernikahan janda dalam masa 'iddah menggunakan qiyas aulawi, maka hukumnya adalah tidak diperbolehkan. Hakum ini di-qiyas-kan dengan larangan meminang perempuan dalam masa 'iddah. Logikanya, meminang perempuan dalam masa 'iddah saja tidak boleh, apalagi menikahinya.

Ustadz Surya Langka menegaskan lagi, 'iddah yang berada dalam talak raj'i sebenarnya pasangan suami istri masih harus berada dalam satu rumah.Ini berkaitan dengan hikmatut tasyri dari 'iddah.Karena salah satu fungsi 'iddah adalah sebagai media suami istri untuk rujuk kembali.Ibrahim Muhammad Al-Jamal dalam bukunya yang berjudul Fiqih Wanita memaparkan bahwa:

Bagi wanita yang sedang menunggu habisnya masa 'iddah, ia punya kewajiban untuk tetap tinggal di rumah suaminya, sampai habis 'iddah-nya.Ia tidak diperkenankan keluar, dan suaminya pun tidak boleh mengusirnya dari situ.

Adapun kalau talak atau perceraian itu jatuhnya pada saat ia tidak berada di rumah suami, maka begitu mendngar ia diceraikan, langsung ia wajib kembali ke rumah suaminya.

Penjelasan di atas sesuai dengan Firman Allah Swt Q.S. At Thalaq [65].

Adapun Hukum Perkawinan di Indonesia yang tertuang dalam Kompilasi Hukum Islam (KHI) Pasal 12 ayat (1) dan (2) dijelaskan bahwa: Peminangan dapat dilakukan terhadap seorang wanita yang masih perawan atau terhadap janda yang telah habis masa iddahnya. Wanita yang ditalak suami yang masih berada dalam masa iddah raj'iah, haram dan dilarang untuk dipinang. ${ }^{21}$

Hal ini yang kemudian berkaitan dengan keharusan pelaksanaan pernikahan yang sesuai dengan tuntunan Agama Islam dan Hukum Perkawinan di Indonesia. Undang-Undang No. 1 Tahun 1974 tentang

${ }^{21}$ Tim Penyusun, Undang-Undang, h. 231. 
Perkawinan Pasal 2 memuat mengenai: Perkawinan adalah sah, apabila dilaksanakan menurut hukum masing-masing agamanya dan kepercayaannya itu. Tiap-tiap perkawinan dicatat menurut peraturan perundang-undangan yang berlaku. ${ }^{22}$

A. Gani Abdullah menjelaskan bahwa suatu pernikahan baru dikatakan perbuatan hukum (menurut hukum) jika berdasarkan hukum yang berlaku secara positif. Perkawinan dengan tata cara seperti itu mempunyai hak atas pengakuan dan perlindungan secara hukum. ${ }^{23}$ Selanjutnya dalam masalah pernikahan janda dalam masa 'iddah, peneliti menitik beratkan pendalaman bahasan pada 'iddah tiga kali quru' (berkenaan dengan 'iddah talak raj'i yang peneliti temukan di masyarakat).Dari ke lima informan peneliti yakni Ustadz Yamin Mukhtar, Ustadz Chairuddin Halim, Ustadz Adri Nasution, Ustadz Iskandar Arsyad dan Ustadz Surya Langka, semuanya memiliki pendapat sama tentang pengertian quru' yakni suci. Para Ulama megartikan quru' sebagai suci dengan bersandar pada pendapat masyhur klasik seperti Imam Syafi'i. Wahbah Zuhaili dalam bukunya yang berjudul Fiqih Imam Syafi'i menjelaskan bahwa: 'Iddah menurut bahasa diambil dari kata 'adad, mengingat 'iddah umumnya mencakup bilangan suci atau bulan.Kalimat "Iddah al-mar'ah" artinya hari-hari suci wanita.Ia mengikuti wazan fi'lah dari kata 'add 'hitungan', artinya hari dan masa suci yang dapat dihitung. Bentuk jamak 'idad. ${ }^{24}$ Dalil yang menyatakan bahwa quru' berarti masa suci adalah hadits riwayat Umar, Ali, Aisyah dan sahabat lainnya, yang diperkuat firman Allah Swt, "Hendaklah kalian ceraikan mereka pada waktu mereka dapat (menghadapi) 'iddahnya (yang wajar)," (QS. Ath-Thalâq [65: Menceraikan istri dalam kondisi haid hukumnya haram.Karenanya, perceraian tersebut boleh dilakukan pada masa suci.Kata 'quru berasal dari kata jam'u (mengumpulkan).Makna ini terwakili dalam kata "persucian” yang tentunya lebih tepat daripada makna "haid". Sebab dalam kondisi suci,

\footnotetext{
${ }^{22}$ Tim Penyusun, Undang-Undang, h. 2.

${ }^{23}$ Ibid., h. 22.

${ }^{24}$ Wahbah Zuhaili, Fiqih Imam Syafi'i: Mengupas Masalah Fiqhiyah Berdasarkan Al-
} Qur'an dan Hadits 3, h. 1. 
seorang wanita dewasa dalam rahimnya terjadi proses menghimpun darah, sedangkan haid, mengeluarkan darah dari rahim. Makna yang sesuai dengan devinisinya tentu lebih utama digunakan daripada makna lain. ${ }^{25}$

Bersikap hati-hati dalam mengambil ketentuan makna quru', ke lima Ulama Palangka Raya sepakat mengambil pengertian yang dipakai mayoritas Ulama yakni suci. Imam Syafi'i telah menjelaskan bahwa makna quru' yang disebutkan dalam Al-Qur'an memang memiliki makna ambigu.Namun makna yang sesuai dengan isi ayat Al-Qur'an di atas adalah suci. Maka, makna suci lebih diutamakan dari pada makna yang lain.

Syaikh Ahmad Musthafa al-Farran dalam bukunya yang berjudul Tafsir Imam Syafi'i Menyelami Kedalaman Kandungan Al-Qur'an Jilid 1 menjelaskan bahwa:

Jika ditanyakan, 'Apa dalil bahasa (lisan)nya?' Jawabnya, quru' adalah suatu kata yang memiliki makna tertentu.Telah diketahui bahwa haid adalah darah yang keluar dari rahim, sedangkan masa suci adalah terhentinya darah.Dalam bahasa Arab bahwa quru' artinya terhenti.",26

Dengan membandingkan dalil-dalil al-Qur'an dan as-Sunnah, ketika

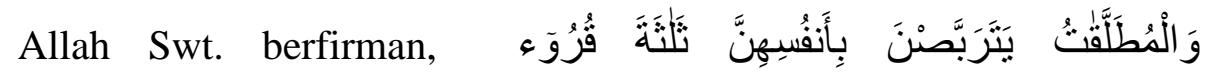
'Perempuan-perempuan yang ditalak hendaklah menahan diri (menunggu) tiga kali quru'.' Rasulullah Saw. menunjukkan bahwa quru’ adalah suci. Sesuai dengan sabda Rasulullah Saw.kepada Ibnu Umar ra.,

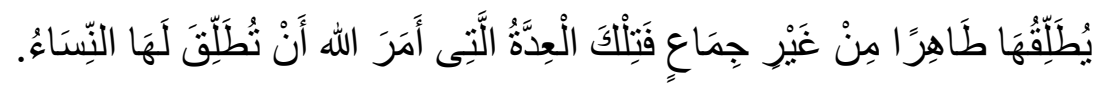

'Menalak istri yang sedang suci, tanpa dicampuri sebelumnya. Maka itulah iddah yang diperintahkan Allah untuk menceraikan istri.'

\footnotetext{
${ }^{25}$ Ibid., h. 5 .

${ }^{26}$ Syaikh Ahmad Musthafa al-Farran, Tafsir Imam Syafi'i Menyelami Kedalaman Kandungan Al-Qur'an Jilid 1: Surah al-Fatihah - Surah Ali 'Imran, Riyadh: Dar AtTadmuriyyah, 2006, h. 382.
} 
Maka kami perintahkan kepada perempuan untuk menunggu sampai tiga kali suci.Jadi haid menjadi pemisah antara suci yang satu dengan suci yang lainnya.Adapun sabda Nabi Saw. Pada budak perempuan berikut,

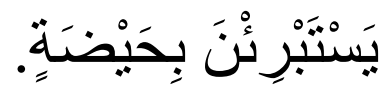

\section{'Mereka suci dengan sekali haid'27}

Dapat diketahui bahwa arti quru' yang sebenarnya adalah suci, sebagaimana pendapat Imam Syafi'i yang masyhur dikalangan para Ulama.Pendapat ini kemudian disepakati para Ulama yang peneliti jadikan subjek penelitian, bahwa mereka mengartikan quru' sebagai masa suci diantara dua haid.Ini didasari dari hukum Allah Swt. yang tertuang dalam AlQur'an sebagai hujjah utama dalam memperoleh ketentuan-ketentuan pokok dalam hukum Islam.

Secara keseluruhan, fenomena pernikahan dalam masa 'iddah seperti ini bertolak belakang dari teori maqasid asy-syari'ah (tujuan hukum Islam), Allah Swt. yang mensyariatkan bahwa hukum-Nya bertujuan untuk memelihara terhadap keturunan atau hifzh al-nasl.Memelihara keturunan dalam tingkat dharuriyyat adalah seperti pensyariatan hukum perkawinan dan larangan berzina. Apabila ketentuan ini diabaikan maka eksistensi keturunan akan terancam. ${ }^{28}$ Sama dengan sifat nikah yang batal karena pernikahan terjadi saat perempuan masih menjalani masa 'iddah.Sehingga, tujuan Hukum Islam yang hendak dicapai akan rusak, karena cacatnya pemeliharaan terhadap keturunan.

Adapun seperti yang peneliti ungkapkan pada bab II tentang 'iddah yang bersifat ta'abuddi atau ibadah, memberikan dampak terhadap kewajiban dari 'iddah itu sendiri. Bahwa tidak ada istilah rukhsah atau keringanan dalam perhitungan 'iddah yang dijalankan seorang janda, baik cerai hidup

\footnotetext{
${ }^{27}$ Ibid., h. 384.

${ }^{28}$ Mardani, Hukum Islam: Pengantar Hukum Islam di Indonesia, Yogyakarta: Pustaka Pelajar, 2010, h. 23.
} 
maupun cerai mati.Jadi, hukum pernikahan janda dalam masa 'iddah seperti ini jelas keharamannya.Jika dukhul, maka hubungan suami istri di anggap zina, dan akibatnya berdampak pada status anak, waris dan sebagainya.

Satria Effendi M. Zein dalam bukunya yang berjudul Problematika Hukum Keluarga Islam Kontemporer: Analisis Yurisprudensi dengan Pendekatan Ushuliyah bahwa,

Nikah wanita yang sedang beriddah, nikah seperti ini jika sempat bersenggama setelah masing-masing mengetahui nikahnya batal, maka perbuatannya di anggap zina.Dan jika keduanya benar-benar belum mengetahui batalnya pernikahan itu atau tidak mengetahui adanya larangan menikahi wanita yang sedang beriddah karena baru masuk Islam misalnya, maka perbuatannya tidak di anggap zina, tetapi senggama subhat. ${ }^{29}$

Sebelumnya Ustadz Chairuddin Halim menjelaskan, jika pernikahan yang batal tersebut pasangan suami istri itu melakukan senggama sampai memiliki anak, dan sepanjang itu pula tidak pernah dibatalkan nikahnya, maka status anak itu tidak jelas. Ustadz Surya Langka dalam tanggapan beliau menjelaskan, ada perbedaan antara orang yang tahu hukum dan orang yang tidak tahu hukum. Kalau seseorang melanggar hukum karena tidak tahu maka tidak ada hukum yang menimpa sebagai akibatnya. Berbeda dengan orang yang tahu, maka jelas hukum selalu mendampinginya. Hal ini sejalan dengan pandangan Wahbah Zuhaili bahwa, pada dasarnya suatu akad seperti akad nikah bila ternyata batal, maka tidak mempunyai hukum. Dan apabila terjadi senggama, hubungan suami istri itu tidak dianggap zina asalkan benarbenar tidak tahu hukum tentang itu. Akibatnya pun tidak pula di dera 100 kali bagi seorang yang belum pernah kawin, tidak pula di rajam bagi yang suidah pernah menikah. Jadi akibat hukumnya sama dengan yang terjadi dalam pernikahan sah, bahkan mengenai nasab anak.

Dari penjelasan sebelumnya, dapat ditarik kesimpulan bahwa sifat pernikahan yang fasid disebabkan tidak sempurnyanya rukun dan syarat sah nikah seperti pernikahan yang dilangsungkan pada masa 'iddah yang belum

${ }^{29}$ Satria Effendi, Problematika Hukum Keluarga Islam Kontemporer: Analisis Yurisprudensi dengan Pendekatan Ushuliyah, Jakarta: Kencana, 2004, h. 24. 
habis, maka hukumnya haram. Adapun langkah hukum yang diambil untuk menuntaskan masalah ini adalah fasakh nikah. Kemudian ada sisa kewajiban 'iddah yang belum selesai untuk dilanjutkan oleh perempuan tadi, dengan memperhatikan kewajiban adabnya ketika 'iddah kembali berlangsung. Selanjutnya jika masa 'iddah-nya sudah berakhir, maka barulah perempuan tersebut bisa melangsungkan pernikahan dengan akad baru sesuai dengan tuntunan Agama dan Hukum Perkawinan di Indonesia. Inilah hukum-hukum Allah Swt yang tidak boleh dilanggar. Karena ajaran-ajaran yang diberikan oleh Allah Swt merupakan ajaran yang paling sempurna. Ini adalah bukti bahwa ada keindahan dalam setiap hukum Islam.

Berdasarkan hasil wawancara dengan beberapa Ulama Kota Palangka Raya yang menjadi subjek penelitian ini, yaitu Ustadz Yamin Mukhtar, Ustadz Chairuddin Halim, Ustadz Adri Nasution, Ustadz Iskandar Arsyad dan Ustadz Surya Langka tersebut, secara umum memiliki kesamaan pendapat bahwa landasan hukum pernikahan janda dalam masa 'iddah telah rinci disebutkan dalam Al-Qur'an, pada Surat Al Baqarah dari ayat 228, 229, 230, 231, 232, dan 234 dan Surat At Thalaq dari ayat 1, 2, 4, 6 dan 7.

Pada ayat ke 228 dijelaskan mengenai kewajiban 'iddah perempuan yang diceraikan suaminya. Dalam ayat ini Allah Swt. mengatur mengenai 'iddah talak raj'i yang harus dipenuhi perempuan tersebut. Dijelaskan pula talak raj'i tidak menyebabkan hubungan suami istri putus seketika, karenanya suami masih memiliki hak untuk rujuk dengan istri yang ditalaknya, asal masih berada dalam masa 'iddah itu. Hal ini berdasarkan firman Allah dalam Q.S. Al Baqarah [2]: 229. Telah dijelaskan bahwa talak yang bisa dirujuki adalah dua talak yang pertama, sehingga pada kesempatan talak yang terakhir (ketiga), suami boleh menahan atau melepaskan istrinya dengan cara yang baik. Dan dijelaskan pula mengenai mahar yang diberikan suami sebelumnya tidak boleh diminta kembali, karena hal seperti itu adalah perbuatan zalim. Kecuali istri ridha, maka suami tidak berdosa untuk menerima 
kembali. ${ }^{30}$ Dalam terjemahan Ibnu Katsir jilid 1 dijelaskan bahwa Allah Swt. membatasi laki-laki hanya sampai tiga kali talak dan member hak untuk rujuk hanya pada talak satu dan dua. ${ }^{31}$ Dalam ayat 230, dijelaskan jika terjadi talak tiga kali, maka talak tersebut adalah talak ba'in qubra, dan tidak boleh dirujuk lagi. Konsekuensinya jika ingin kembali, maka perempuan harus menikah dengan laki-laki lain kemudian cerai.Baru setelah itu bisa kembali dengan suami yang sebelumnya dengan akad nikah baru.Ini merupakan aturan Allah Swt yang tidak bisa dilanggar. ${ }^{32}$ Kemudian dalam ayat ke 231 dijelaskan bahwa ketika suami menceraikan istrinya harus rujuk dengan baik atatu tetap bercerai dengan cara yang baik pula. Dan suami dilarang untuk mempermainkan hukum Allah Swt. dengan maksud zalim kepada perempuan ketika merujukinya. ${ }^{33}$ Selanjutnya dalam ayat 232 dilarang bagi suami untuk menghalang-halangi mantan istrinya untuk menikah dengan laki-laki lain ketika 'iddah-nya telah terpenuhi. ${ }^{34}$ Pada ayat ke 234 dijelaskan mengenai hitungan 'iddah bagi istri yang ditinggal mati adalah selama 4 bulan 10 hari. Kemudian dalam ayat ke 235 dijelaskan bahwa diperbolehkan untuk meminang perempuan tersebut dengan sindiran (tidak diperbolehkan secara terang-terangan) dengan perkataan yang baik. ${ }^{35}$ Ayat 1 dan 2 Surah At Thalaq ini menjelaskan tentang kewajiban suami untuk menceraikan istri dalam keadaan suci dari haid dan tidak dicampuri. Agar pihak istri dalat melaksanakan 'iddah-nya dengan wajar.Dan dijelaskan pula bahwa istri tidak diperkenankan keluar rumah baik diperintahkan suami atau dengan inisiatifnya sendiri, kecuali jika istri berbuat maksiat.Diperintahkan untuk memanggil dua orang saksi yang adil jika istri mendekati akhir 'iddah-nya dan suami ingin menahan atau melepaskan istrinya.Apabila suami ingin

\footnotetext{
${ }^{30}$ Departemen Agama RI, Al-Qur'an Bayan: Al-Qur'an dan Terjemahannya disertai Tanda-Tanda Tajwid dengan Tafsir Singkat, h. 36.

${ }^{31}$ Bahreisy, Salim dan Said Bahreisy (pengh. dan pent.), Terjemah Singkat Tafsir Ibnu Katsir Jilid 1, h. 441.

${ }^{32}$ Departemen Agama RI, Al-Qur'an Bayan: Al-Qur'an dan Terjemahannya disertai Tanda-Tanda Tajwid dengan Tafsir Singkat, h. 37.

${ }^{33}$ Ibid.

${ }^{34}$ Ibid.

${ }^{35}$ Departemen Agama RI, Al-Qur'an Bayan: Al-Qur'an dan Terjemahannya disertai Tanda-Tanda Tajwid dengan Tafsir Singkat, h. 38.
} 
merujuk kembali, maka jalan untuk itu telah tertutup ketika masa 'iddah yang dijalani istrinya sudah. Dalam Q.S. At Thalaq [65]: 4- 7 ketiga ayat di atas menjelaskan tentang hitungan bagi perempuan yang menopause adalah selama 3 bulan.Sama dengan wanita yang tidak pernah haid, maka iddah-nya 3 bulan. Kemudian menjelaskan mengenai fasilitas yang harus diberikan suami kepada istrinya selama menjalani masa iddah, yakni tempat tinggal dan nafkah sesuai kemampuan suami. Jika istrinya hamil, maka berikan nafkah kepada istri sampai ia melahirkan. Ketika istri melahirkan maka suami harus memberikan nafkah berupa imbalan kepadanya karena telah menyusui anaknya. Allah Swt memerintahkan pemberian nafkah dan tempat tinggal dari suami tidak untuk mempersulit, melainkan Allah Swt. memerintahkan sesuai dengan batas kemampuan hamba-Nya. ${ }^{36}$ Secara khusus, Ustadz Yamin Mukhtar, Ustadz Chairuddin Halim, dan Ustadz Surya Langka menyampaikan landasan hukum pernikahan janda dalam masa iddah bisa dilihat pada Surat Al Baqarah ayat ke 228, 229, 230, 231, 232, dan 234 serta Surat At Thalaq ayat 1, 2, 4, 6 dan 7. Ustadz Surya Langka menjelaskan bahwa ada keistimewaan tersendiri terhadap perihal talak dan 'iddah, karena Allah Swt memberikan tempat tersendiri dalam Al-Qur'an untuk pembahasan itu. Ini menggambarkan bahwa sekalipun itu masalah talak dan 'iddah, tapi harus sesuai dengan syariat yang diatur.Sejalan dengan itu, Ustadz Chairuddin Halim juga menyatakan bahwa masalah ini adalah masalah Fikih, dan ketentuan Fikih tidak bisa dilanggar.Karena ketentuan-ketentuan dalam Fikih adalah ketentuan-ketentuan mutlak dari Allah Swt yang merupakan ibadah, khususnya dalam hal 'iddah. Selanjutnya, Ustadz Adri Nasution dan Ustadz Iskandar Arsyad yang sama-sama berorientasi dalam lingkup praktisi hukum. Karena itu, beliau berdua menambahkan bahwa Hukum Perkawinan Indonesia juga menjadi landasan ketentuan-ketentuan perkawinan, talak dan 'iddah. Hukum Perkawinan di Indonesia termasuk Kompilasi Hukum Islam (KHI) yang menjadi pedoman masyarakat di Indonesia, merupakan produk

\footnotetext{
${ }^{36}$ Departemen Agama RI, Al-Qur'an Bayan: Al-Qur'an dan Terjemahannya disertai Tanda-Tanda Tajwid dengan Tafsir Singkat, h. 559.
} 
Hukum Positif Indonesia yang berpedoman langsung pada Al-Qur'an dan hadis. Sehingga sedikit banyaknya, Hukum Perkawinan Indonesia memberikan ketentuan- ketentuan yang sejalan dengan syariat Hukum Islam.

Ustadz Adri Nasution menyampaikan bahwa landasan hukum dalam permasalahan ini adalah Al-Qur'an, hadis, ijma', qiyas, Undang-Undang No.1 tentang Perkawinan Tahun 1974 dan Kompilasi Hukum Indonesia. Selain berdasarkan pada hukum agama, perihal pernikahan di Indonesia juga memakai beberapa dari produk Hukum Positif di Indonesia. Dalam UndangUndang No. 1 Tahun 1974 tentang Perkawinan Pasal 40 huruf b disebutkan bahwa, seorang wanita yang masih berada dalam masa 'iddah dengan mantan suaminya, maka dilarang melangsungkan pernikahan dengan laki-laki lain. Selanjutnya mengenai perhitungan 'iddah bagi seorang perempuan talak raj' $i$ ditetapkan dalam Undang-Undang No. 1 Tahun 1974 tentang Perkawinan Pasal 153 ayat (2) huruf b bahwa, waktu tunggu bagi perempuan itu adalah tiga kali quru' atau sekurang-kurangnya 90 hari. Menurut Ustadz Iskandar Arsyad, Hukum Perkawinan Indonesia memperkirakan masa tiga kali quru'selama 90 hari seperti ini adalah untuk ikhtiati dalam membuat ketentuan dan bertujuan untuk kemashlahatan bagi yang bersangkutan.Pengambilan angka yang maksimal diharapkan mampu memberikan kesempurnaan hikmah 'iddah, seperti kepastian kosongnya rahim, masa transisi, dan tentunya syariat Islam sendiri.

Dari penjelasan yang padat melalui argumentasi dari 5 Ulama Palangka Raya, yakni Ustadz Yamin Mukhtar, Ustadz Chairuddin Halim, Ustadz Adri Nasution, Ustadz Iskandar Arsyad, dan Ustadz Surya Langka, maka pendapat beliau semua bisa dijadikan sebagai hujjahdan pernyataannya bisa dipertanggungjawabkan karena ada kehati-hatian dalam pengambilan hukum yang terkandung didalamnya. Adapun dalam kajian qawaid fiqh atau kaidah fikih, mengikuti pendapat Ulama adalah kewajiban bagi umat Islam. Karena eksistensi Ulama sebagai imam wajib diikuti kebenarannya.

Dalam Qawaid Fiqh, terdapat kaidah fikih dalam ruang lingkup siyasah/ politik, salah satunya yaitu: 


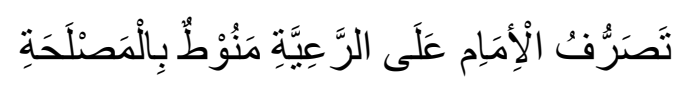

Terjemahan:"Tindakan imam terhadap rakyatnya harus dikaitkan dengan kemaslahatan." 37

\section{E. Kesimpulan}

Berdasarkan hasil penelitian dan analisis data yang telah dilakukan penulis di atas, maka dapat disimpulkan yaitu: Hukum pernikahan janda dalam masa 'iddah menurut pandangan Ulama Palangka Raya adalah haram karena bersifat fasid, disebabkan tidak sempurnanya syarat pernikahan. Menurut tujuan Hukum Islam atau maqasid asy-syari'ah mengenai pernikahan bahwa, pernikahan dilakukan untuk mencegah terjadinya mafsadat, seperti zina. Pernikahan dalam masa iddah tidak hanya berdampak pada pasangan suami istri tadi, tapi juga berdampak pada status anak, status harta, waris dan lain sebagainya. Dalam ketentuan Hukum Perkawinan di Indonesia ada pula Undang-Undang No. 1 Tahun 1974 tentang Perkawinan dan Kompilasi Hukum Islam (KHI). Hal ini menegaskan bahwa iddah bersifat prinsip dan tidak bisa ditinggalkan bagi orang-orang yang memiliki tanggungan terhadapnya. 'Iddah merupakan salah satu pokok dalam Hukum Islam, dimana dalam menjalankannya adalah bentuk kesempurnaan tujuan hukum Islam khususnya dalam hal talak.

\section{Daftar Pustaka}

Azziz Muhammad Azzam, Abdul dan Abdul Wahab Sayyed Hawwas, Fiqh Munakahat: Khitbah, Nikah, dan Talak, Alih bahasa Abdul Majid Khon, Jakarta: Amzah, 2009.

Benri, "Pengabaian Masa Idah (Studi Kasus di Kecamatan Kurun Kabupaten Gunung Mas", Skripsi Sarjana, Palangkaraya: Sekolah Tinggi Agama Islam Negeri (STAIN) Palangkaraya, 2007, t.d.

Departemen Agama RI, Al-Qur'an Bayan: Al-Qur'an dan Terjemahannya disertai Tanda-Tanda Tajwid dengan Tafsir Singkat, t.tm: Bayan Qur'an, 2009.

\footnotetext{
${ }^{37}$ Nurvita Diah Rahayu, Kaidah Fiqhiyah, http://nurvita-diahrahayu.blogspot.co.id/2012/03/kaidah-fiqhiyah.html, di akses tanggal 20 November 2015.
} 
Dewan Penterjemah, Al Qur'an dan Terjemahannya, Madinah: Mujamma' Al Malik Fahd Li Thiba'at Al Mush-haf, 1971.

Djazuli, A., Kaidah-Kaidah Hukum Islam dalam Menyelesaikan MasalahMasalah yang Praktis, Jakarta: Kencana; 2006, h. 147.

Mahmud, Yunus, Hukum Perkawinan dalam Islam, Jakarta: CV Al Hidayah, 1964.

MK, M. Ansyari, Hukum Perkawinan di Indonesia, Yogyakarta: Pustaka Pelajar, 2010.

Mardani, Hukum Islam: Pengantar Hukum Islam di Indonesia, Yogyakarta: Pustaka Pelajar, 2010.

Munasir, "Penetapan Masa Idah Wanita yang Dicerai dalam Perspektif Empat Imam Mazhab Fikih dan Hakim Pengadilan Agama Palangkaraya", Skripsi Sarjana, Palangkaraya: Sekolah Tinggi Agama Islam Negeri (STAIN) Palangkaraya, 2014, t.d.

Nurvita Diah Rahayu, Kaidah Fiqhiyah, http://nurvita-diahrahayu.blogspot.co.id/2012/03/kaidah-fiqhiyah.html, di akses tanggal 20 November 2015.

Rasyid Rijani, Kaidah Fiqh tentang Pencatatan Perkawinan dan Perceraian, http://konsultasi-hukum-online.com/2013/05/kaidah-kaidah-fiqhiyyahtentang-pencatatan-perkawinan-di-kua-dan-perceraian-di-pengadilanagama/, di akses pada 20 November 2015.

Sabiq, Sayyid, Fiqih Sunnah 3, Alih bahasa M. Ali Nursyidi dan Hunainah M. Thahir Makmun, Jakarta: PT. Pena Pundi Aksara, 2009.

Syarifuddin, Amir, Hukum Pernikahan Islam di Indonesia: ANtara Fiqh Munakahat dan Undang-Undang Perkawinan, Jakarta: Kencana, 2009.

Tim Penyusun, Himpunan Peraturan Perundang-Undangan TentangKompilasi Hukum Islam, Bandung: Fokus Media, 2007.

Zuhaili, Wahbah, Fiqih Imam Syafi'i: Mengupas Masalah Fiqhiyah Berdasarkan Al-Qur'an dan Hadits 2, Jakarta: Almahira, 2010. 